\title{
Pengembangan Handout IPA Berbasis Lingkungan Alam Sekitar Dipadu Peta Konsep
}

\author{
Dyah Ayu Fajarianingtyas, Ach. Musthofa Helmy Huda \\ Prodi Pendidikan IPA, FKIP Universitas Wiraraja \\ *Coresponding author: azrilarkan@gmail.com
}

\section{AR T I C LE INF O}

Article history:

Received: Mei 2019

Accepted: September 2019

\section{Keywords:}

Handout IPA, lingkungan

alam sekitar, peta konsep,

kelayakan bahan ajar, respon

\begin{abstract}
ABSTRAK
Penelitian ini bertujuan (1) untuk mengetahui kelayakan handout IPA berbasis lingkungan alam sekitar dipadu peta konsep dan (2) respon dari peserta didik dan guru. Subjek penelitian adalah peserta didik kelas VIII SMPI Al-Aziz sebanyak 11 orang. Jenis penelitian yang digunakan yaitu Research and Development (R \& D) dengan model penelitian Four D yang di awali dengan tahap pendefinisian, rancangan dan pengembangan. Instrumen penelitian menggunakan lembar validasi dan lembar respon. Hasil penelitian yang didapatkan dari validasi kelayakan handout IPA berbasis lingkungan alam sekitar dipadu peta konsep oleh ahli yaitu kelayakan materi sebesar 94\% (kategori sangat layak), kelayakan lingkungan alam sekitar sebesar $100 \%$ (kategori sangat layak), kelayakan peta konsep sebesar 96\% (kategori sangat layak), dan kelayakan desain sebesar 91\% (kategori sangat layak). Hasil penyebaran angket respon berupa respon peserta didik kelas sebesar $82 \%$ (kategori sangat baik tanpa revisi) dan respon guru sebesar $89 \%$ (ketegori sangat baik tanpa revisi).
\end{abstract}

\section{PENDAHULUAN}

Pendidikan merupakan aspek penting dalam meningkatkan kualitas sumber daya (Prastowo, 2012) menyatakan bahwa bahan ajar merupakan segala bentuk bahan yang digunakan oleh guru atau peserta didik dalam proses belajar mengajar di kelas, bahan ajar tersebut berupa teks, informasi ataupun alat sehingga tercipta suasana pembelajaran yang baik. Bahan ajar memiliki jenis, bentuk, cara kerja, dan sifatnya. Salah satu bahan ajar yaitu handout, (Prastowo, 2012). Bahan ajar merupakan segala bentuk bahan yang digunakan oleh guru atau peserta didik dalam proses belajar mengajar di kelas, bahan ajar tersebut berupa teks, informasi ataupun alat sehingga tercipta suasana pembelajaran yang baik (Ali \& Arif, 2019). Bahan ajar memiliki jenis, bentuk, cara kerja, dan sifatnya (Yusnaeni, Lika, \& Hiul, 2019; Lestari, Ristanto, \& Miarsyah, 2019). Salah satu bahan ajar yaitu handout, (Fajarianingtyas, Akbar, \& Herowati, 2019; Prastowo, 2012). 
Handout merupakan bahan ajar tertulis untuk memberikan kemudahan bagi peserta didik untuk belajar dan melengkapi kekurangan materi yang terdapat dalam buku pelajaran yang digunakan (Prastowo, 2012). Handout disiapkan oleh pendidik untuk memperkaya pengetahuan peserta didik dalam mendapatkan informasi (Majid, 2011). Informasi dapat diperoleh melalui melalui buku pelajaran, karya ilmiah, alam, lingkungan sekitar, dan lain-lain.

Mariyana, Nugraha (2013) menyatakan bahwa lingkungan merupakan suatu keadaan yang dapat mempengaruhi pertumbuhan dan perkembangan seseorang. Proses pembelajaran akan berjalan baik apabila dalam pembelajaran yang berlangsung memanfaatkan lingkungan alam sekitar peserta didik. (Lamasai, 2014) menyatakan bahwa lingkungan memiliki manfaat yang besar untuk menunjang kegiatan pembelajaran secara optimal. (Lamasai, 2014) juga menyatakan bahwa dengan menggunakan lingkungan maka pembelajaran akan lebih bermakna dan bernilai, karena peserta dididk dapat mengetahui keadaan yang lebih nyata, faktual, dan harus dipertanggung jawabkan. Memanfaatkan lingkungan alam dapat membuat peserta didik berinteraksi dengan lingkungan atau objek yang dipelajarinya, sehingga peserta didik akan aktif dalam mengkontruksi pengetahuannya sendiri (Ristanto, 2011). Lingkungan alam yang digunakan dalam bahan ajar yang dikembangkan mencakup segala sesuatu baik itu benda atau objek di alam yang berorientasi sesuai dengan lingkungan peserta didik dan kebutuhan peserta didik. Peserta didik sebelum belajar harus mengetahui hubunganhubungan antar konsep untuk memudahkan saat proses belajar berlangsung. Hal tersebut dapat diperoleh dari peta konsep yang menghubungkan konsep satu dengan yang lainnya tentang materi yang akan dipelajari.

Trianto (2010) mengemukakan bahwa dengan peta konsep dapat mengindikasikan konsep-konsep yang berhubungan dengan konsep yang lainnya. Peta konsep merupakan ilustrasi grafis yang menginformasikan hubungan konsep-konsep lain namun tetap dalam kategori yang sama. Peta konsep terdapat empat macam, yaitu pohon jaringan, rantai kejadian, peta konsep siklus dan peta konsep laba-laba. Peta konsep diperuntukan agar peserta didik lebih memahami sesuatu yang kompleks yang sedang dipelajari dalam suatu ilustrasi grafis yang simple (Trianto, 2010).

SMPI Al-Aziz merupakan sekolah yang baru dua tahun berdiri dan masih terdapat dua kelas, yaitu kelas VII dan VIII. Sarana dan prasarana di sekolah tersebut masih belum cukup untuk menunjang proses belajar mengajar berjalan dengan baik, seperti keterbatasan bahan belajar untuk peserta didik yang digunakan di luar sekolah, alat praktikum, dan lain sebagainya.

Hasil wawancara dengan peserta didik dan guru IPA diperoleh informasi bahwa peserta didik membutuhkan inovasi bahan ajar baru untuk membantu proses belajar IPA karena ketersediaan bahan ajar di SMPI Al-Aziz dalam jumlah terbatas. Hasil anailisis buku paket Belajar IPA Membuka Cakrawala Alam Sekitar kelas VIII kurikulum 2006 yang digunakan oleh SMPI Al-Aziz terdapat kelemahan-kelemahan yang perlu diperbaiki, yaitu materi yang disajikan sangat padat, peta konsep hanya terdapat pada buku paket Belajar IPA Membuka Cakrawala Alam Sekitar yang dipegang oleh guru, namun peserta didik tidak dapat menggunakannya ketika berada dirumah, dan contoh yang terdapat dalam buku paket tidak disesuaikan dengan karakteristik lingkungan peserta didik. 


\section{METODE PENELITIAN}

Jenis penelitian ini menggunakan penelitian dan pengembangan (Research and Development). Penelitian ini merupakan penelitian yang bertujuan menghasilkan suatu produk. Model yang digunakan dalam penelitian ini yaitu model penelitian Four D yang dikemukakan oleh (Thiagarajan, Semmel, \& Semmel, 1974) yang fokus pada bidang pendidikan. Model Four D terdiri dari empat tahap pengembangan, yaitu define, design, develop dan disseminate. Namun pada penelitian ini terdiri dari tiga tahap, yaitu define, design, develop dan dapat dilihati pada gambar 1 sebagai berikut:

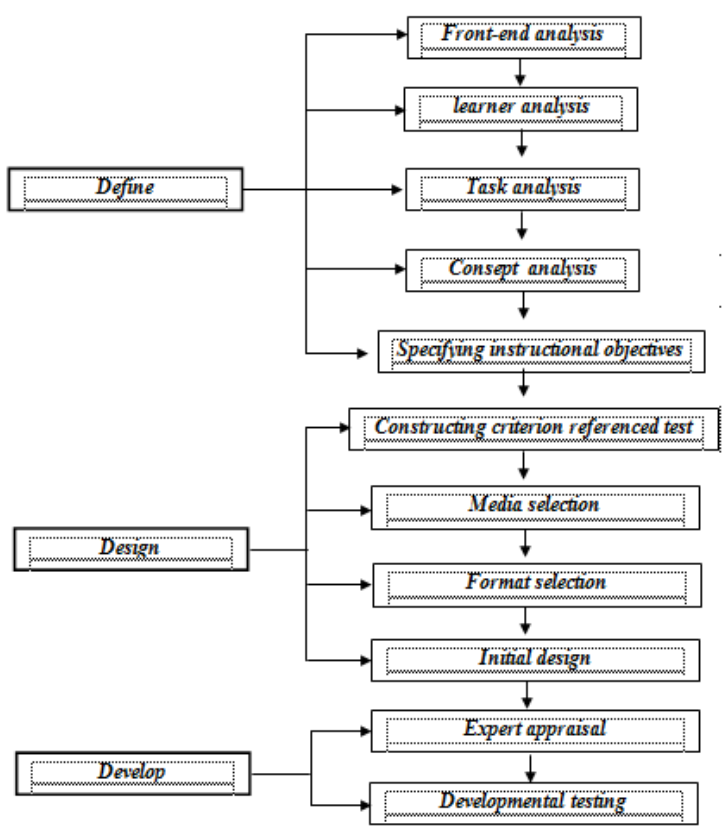

Gambar 1 Langkah-langkah Penelitian Research and Development (Thiagarajan et al., 1974)

Diadaptasi Oleh Peneliti.

Desain penelitian ini merupakan desain uji coba yang dikembangkan oleh Thiagarajan \& Semmel seperti gambar 2 berikut:.

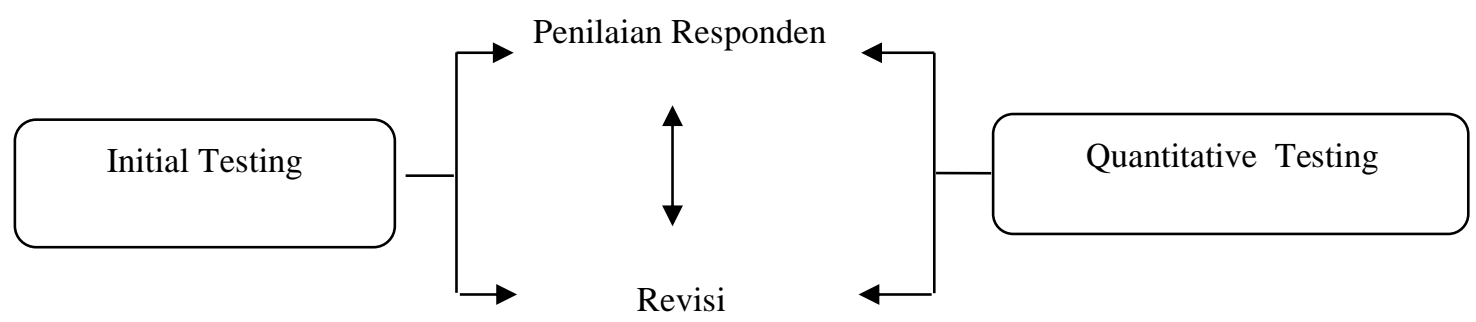

Gambar 2: Desain uji coba yang dikembangkan oleh (Thiagarajan et al., 1974)

Subjek yang digunakan dalam penelitian ini yaitu peserta didik kelas VIII SMPI Al-Aziz sebanyak 11 orang. Jenis data yang digunakan yaitu diperoleh berdasarkan data kuantitatif. Pada data kualitatif yaitu berupa saran dari validator untuk perbaikan dan penyempurnaan produk handout IPA berbasis lingkungan alam sekitar dipadu peta konsep yang dikembangkan. Analisis yang digunakan pada validasi kelayakan lembar kerja siswa yaitu komponen kelayakan materi, format, dan tampilan dengan menggunakan rumus sebagai berikut:

$$
\text { Persentase }=\frac{\text { Jumlah skor total }}{\text { Skor ideal }} \times 100 \%
$$


Adapun kriteria validasi produk handout dapat dilihat pada tabel 1 sebagai berikut:

Tabel 1 Kriteria Validasi Kelayakan Produk

\begin{tabular}{cc}
\hline Persentase Kelayakan & Kategori \\
\hline$<20 \%$ & Tidak Layak \\
\hline $21 \%-40 \%$ & Kurang Layak \\
\hline $41 \%-60 \%$ & Cukup Layak \\
\hline $61 \%-80 \%$ & Layak \\
\hline $81 \%-100 \%$ & Sangat Layak
\end{tabular}

Sumber: (Setiawan \& Wiyardi, 2015)

Analisis yang digunakan pada respon peserta didik dan guru yaitu dengan cara penyebaran angket respon. Hasil penyebaran angket tersebut dianalisis dengan menggunakan rumus sebagai berikut:

$$
\text { Persentase }=\frac{\text { Jumlah skor total }}{\text { Skor ideal }} \times 100 \%
$$

Adapun kriteria validasi produk lembar kerja siswa berbasis pendekatan saintifik dapat dilihat pada tabel 1 sebagai berikut:

Tabel 2 Kriteria Respon

\begin{tabular}{cc}
\hline Persentase Responden & Kategori \\
\hline $85-100 \%$ & Sangat Baik \\
\hline $65-84 \%$ & Baik \\
\hline $45-64 \%$ & Cukup Baik \\
\hline $0-44 \%$ & Kurang Baik \\
\hline
\end{tabular}

Sumber: (Setiawan and Wiyardi, 2015)

\section{HASIL DAN PEMBAHASAN}

Produk yang dihasilkan yaitu handout IPA berbasis lingkungan alam sekitar dipadu peta konsep. Produk tersebut telah melewati tahap validasi kelayakan produk oleh ahli dibidangnya yang meliputi validasi kelayakan materi, peta konsep, lingkungan alam sekitar dan desain (tampilan, format, bahasa, penyajian dan kegunaan). Data hasil validasi kelayakan produk yang dikembangkan dapat dilihat dari hasil penilaian validator. Penilaian validasi kelayakan materi dapat dilihat pada Tabel 3 berikut.

Tabel 3 Data hasil validasi kelayakan materi

\begin{tabular}{cccccc}
\hline \multirow{2}{*}{ Materi } & \multicolumn{3}{c}{ Validator } & & \\
\cline { 2 - 4 } & $(\mathbf{I})$ & $(\mathbf{I I})$ & & Jumlah & Persentase (\%) \\
\hline \multirow{2}{*}{ Gaya } & 16 & 15 & 31 & 97 \\
\cline { 2 - 5 } Usaha dan energi & 28 & 24 & 52 & 93 \\
\cline { 2 - 4 } & 16 & 14 & 30 & 94 \\
\hline tekanan & 28 & 23 & 51 & 91 \\
\hline
\end{tabular}




\begin{tabular}{ccccc}
\hline & 28 & 25 & 53 & 95 \\
\hline \multirow{2}{*}{ Getaran dan gelombang } & 16 & 13 & 29 & 91 \\
\cline { 2 - 5 } & 28 & 24 & 52 & 93 \\
\hline Bunyi & 16 & 15 & 31 & 97 \\
\cline { 2 - 4 } & 28 & 25 & 53 & 95 \\
\hline \multirow{2}{*}{ Cahaya dan alat optik } & 16 & 15 & 31 & 97 \\
\cline { 2 - 4 } & 28 & 26 & 54 & 96 \\
\hline Jumlah skor indikator kualitas isi & 315 \\
\hline $\begin{array}{c}\text { jumlah skor indikator kesesuaian konten dan isi dengan } \\
\text { lingkungan alam sekitar dipadu peta konsep }\end{array}$ & 95 \\
\hline Persentase skor indikator kualitas isi (\%) & 94 \\
\hline $\begin{array}{c}\text { Persentase skor indikator kesesuaian konten dan isi dengan } \\
\text { lingkungan alam sekitar dipadu peta konsep (\%) }\end{array}$ & 94 \\
\hline
\end{tabular}

Data hasil validasi lingkungan alam sekitar peserta didik dapat dilihat pada Tabel 4.

Tabel 4 Data hasil validasi kelayakan lingkungan alam sekitar peserta didik

\begin{tabular}{lccc}
\hline \multirow{2}{*}{ Validator } & $\begin{array}{c}\text { Hasil Penilaian Lingkungan alam } \\
\text { sekitar Peserta didik }\end{array}$ & Jumlah \\
\hline$(1)$ & 22 & 22 \\
\hline (II) & \multicolumn{2}{c}{22} & 22 \\
\hline \multicolumn{2}{c}{ Jumlah } & 44 & 44 \\
\hline \multicolumn{2}{c}{ Persentase (\%) } & 100 & 100 \\
\hline \multicolumn{2}{c}{ Kategori } & Sangat Layak \\
\hline
\end{tabular}

Data hasil validasi peta konsep dapat dilihat pada Tabel 5.

Tabel 6 Data hasil validasi kelayakan desain

\begin{tabular}{|c|c|c|c|c|c|}
\hline \multirow[t]{2}{*}{ Validator } & \multicolumn{4}{|c|}{ Aspek Hasil Penilaian Tampilan } & \multirow[t]{2}{*}{ Jumlah } \\
\hline & $\begin{array}{c}\text { Tampila } \\
\mathrm{n}\end{array}$ & Format & Bahasa & $\begin{array}{c}\text { Penggunaa } \\
n\end{array}$ & \\
\hline (1) & 35 & 32 & 11 & 13 & 91 \\
\hline (II) & 35 & 30 & 11 & 15 & 91 \\
\hline Jumlah & 70 & 62 & 22 & 28 & 182 \\
\hline Persentase $(\%)$ & 88 & 97 & 92 & 88 & 91 \\
\hline Kategori & & & Sanga & Layak & \\
\hline
\end{tabular}

Hasil validasi kelayakan materi masuk dalam kategori sangat layak. Kelayakan materi dalam handout IPA berbasis lingkungan alam sekitar dipadu peta konsep dinilai oleh ahli materi meliputi dua aspek, yaitu kualitas isi dan kesesuaian materi dengan lingkungan alam sekitar peserta didik dipadu peta konsep. Kualitas isi yang terdapat dalam handout IPA berbasis lingkungan alam sekitar dipadu peta konsep disesuaikan dengan Kurikulum Tingkat Satuan Pendidikan (KTSP) yang digunakan di SMPI Al-Aziz.

Hal tersebut yang 
membuat validator materi memberikan skor sangat baik. Badan Standar Nasional Pendidikan (BSNP) standar kompetensi dan kompetensi dasar untuk SMP/MTs (2006) menyatakan bahwa Ilmu Pengetahuan Alam (IPA) berkaitan dengan cara mencari tahu tentang alam secara sistematis, sehingga IPA bukan hanya penguasaan kumpulan pengetahuan yang berupa fakta-fakta, konsep-konsep, atau prinsip-prinsip saja tetapi juga merupakan suatu proses penemuan. Materi yang terdapat dalam handout IPA berbasis lingkungan alam sekitar dipadu peta konsep terdapat fitur ilmuwan cilik berfungsi untuk meningkatkan berpikir kritis, kreatifitas peserta didik dan menekankan peserta didik untuk melakukan proses penemuan, baik dengan mengamati, menganalisis, dan melakukan percobaan yang sesuai dengan lingkungan alam sekitar peserta didik. Hal ini dapat ditunjukkan pada materi (1) Gaya untuk memahami gaya gesek, (2) Usaha dan Energi untuk memahami energi potensial, (3) Tekanan untuk mengetahui tekanan hidrostatis, archimides, dan tekanan udara, (4) Getaran dan Gelombang untuk memahami getaran, (5) Bunyi untuk memahami cepat rambat bunyi, pemantulan dan penyerapan bunyi, dan (6) Cahaya untuk memahami cacat mata rabun jauh dan kamera.

Fitur ilmuwan cilik mempunyai tujuan agar peserta didik mampu mencari dan menemukan konsep sendiri dari pertanyaan-pertanyaan yang berkaitan dengan lingkungannya. Hal tersebut sesuai dengan teori kontruktivisme, karena peserta didik dalam menggunakan handout IPA berbasis lingkungan alam sekitar dipadu peta konsep dituntut untuk membentuk dan membangun pengetahuan (kognitif) sendiri yang terjadi di lingkungan sekitarnya secara ilmiah (konflik kognitif), (Sumarsih, 2009).

Hasil dari validasi kelayakan lingkungan alam sekitar peserta didik termasuk dalam kategori sangat layak. Kesesuaian konten dan isi dengan lingkungan alam sekitar peserta didik disesuaikan dengan tempat tinggal dan sekolah peserta didik yang berada dalam kawasan pesisir. Konten dan isi yang disesuaikan dengan lingkungan alam sekitar peserta didik berupa contoh, pertanyaan, gambar, dan kasus-kasus. Mukhyati (2015) menyatakan bahwa konten yang sesuai dengan lingkungan peserta didik sangat penting dalam pembelajaran, karena dapat meningkatkan pemahaman peserta didik dalam memahami materi yang sedang dipelajari.

Hasil validasi dari kelayakan peta konsep termasuk dalam kategori sangat layak. Seluruh materi yang terdapat dalam handout IPA berbasis lingkungan alam sekitar dipadu peta konsep terdapat peta konsep di setiap awal bab materi untuk memudahkan peserta didik dalam mempelajari suatu hal secara keseluruhan. (Hardanti, 2016) mengemukakan bahwa peta konsep merupakan cara untuk membuat peserta didik untuk melihat, membaca dan memahami tentang materi yang dipelajari. Penggunaan handout IPA berbasis lingkungan alam sekitar dipadu peta konsep membuat peserta didik lebih mudah menghubungkan teori yang dipelajari dengan lingkungan sekitarnya, sehingga akan berdampat positif terhadap proses pembelajaran yang terjadi di dalam kelas, pengetahuan peserta didik, dan pengalaman yang sudah diperoleh dilingkungannya.

Hasil validasi kelayakan desain handout IPA berbasis lingkungan alam sekitar dipadu peta konsep tergolong dalam kategori sangat layak. Aspek yang dinilai yaitu tampilan, format, bahasa, penggunaan dan penyajian. (Ratnasari, 2017) mengemukakan bahwa untuk membuat peserta didik berminat untuk membacanya maka tampilan teks harus menarik, terdapat gambar-gambar, dan berwarna agar peserta didik tidak cepat bosan. Aspek format dalam handout IPA berbasis lingkungan alam sekitar dipadu peta konsep dapat digunakan tanpa revisi, karena format yang digunakan sesuai dengan lingkungan alam sekitar pesarta didik baik lingkungan tempat tinggal dan sekolah. (Mukhyati, 2015) bahwa kesesuaian konten didalam suatu bahan ajar dengan lingkungan peserta didik dapat meningkatkan pemahaman peserta didik. Aspek bahasa yang digunakan dalam handout IPA berbasis lingkungan alam sekitar dipadu peta konsep dapat digunakan tanpa revisi, karena bahasa yang digunakan mudah dimengerti oleh peserta didik. (Ratnasari, 2017) menyampaikan bahwa bahan ajar yang baik yaitu bahasa yang 
digunakan komuikatif sehingga mudah dimengerti karena menggunakan kata-kata sederhana namun tidak menyampingkan makna yang sesungguhnya. Aspek penggunaan dan penyajian dapat digunakan tanpa revisi, karena sudah terdapat petunjuk pengguna handout IPA berbasis lingkungan alam sekitar dipadu peta konsep dan disajikan secara berurutan dari bagian pendahuluan yang memuat $S K, K D$, tujuan pembelajaran, peta konsep, isi materi, rangkuman, refleksi dan penutup.

Hasil penilaian yang diperoleh dari validasi kelayakan materi, peta konsep, lingkungan alam sekitar, dan desain dinyatakan layak dan dapat digunakan dalam pembelajaran karena telah memenuhi kriteria kelayakan. Hasil respon peserta didik yang menunjukkan bahwa handout IPA berbasis lingkungan alam sekitar dipadu peta konsep masuk dalam kategori sangat baik. Hasil tersebut menunjukkan bahwa keseluruhan handout IPA berbasis lingkungan alam sekitar dipadu peta konsep yang dikembangkan sangat baik dan layak untuk digunakan dalam proses pembelajaran di kelas. Skor yang diperoleh dari respon setiap peserta didik disajikan pada Gambar 2.

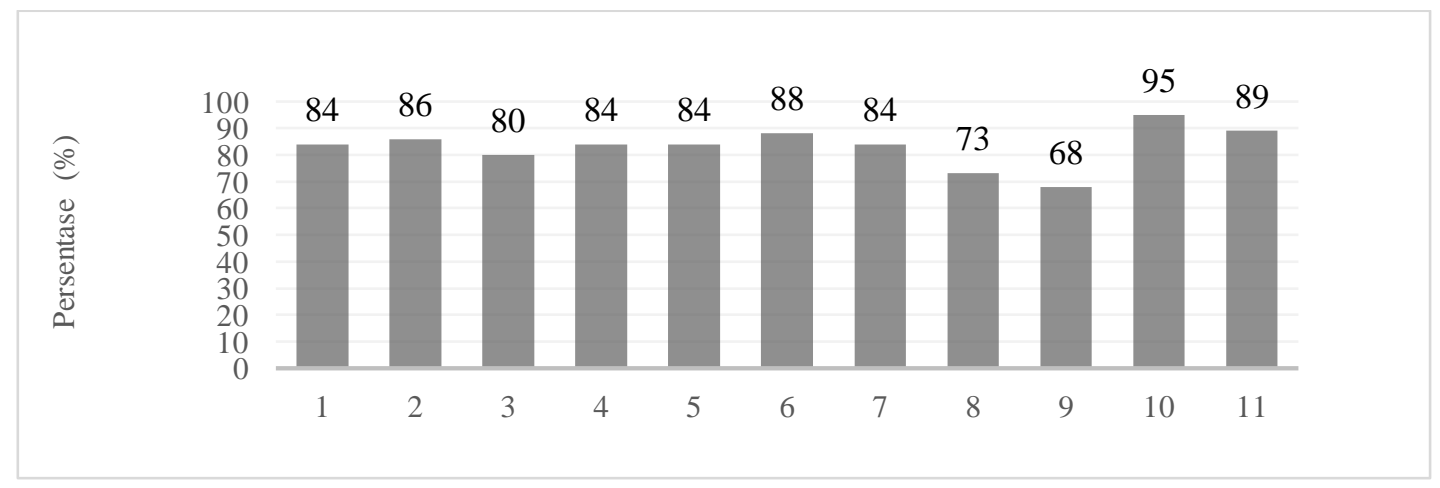

Gambar 2 Hasil angket respon peserta didik.

Data hasil respon guru diperoleh dengan pemberian angket respon guru terhadap handout IPA berbasis lingkungan alam sekitar dipadu peta konsep. Hasil persentase respon guru IPA yaitu 89\% dengan kategori sangat baik dengan keterangan tidak ada revisi. Artinya, secara keseluruhan respon guru di SMPI Al-Aziz terhadap handout IPA berbasis lingkungan alam sekitar dipadu peta konsep yang dikembangkan sangat baik. Respon guru dapat dilihat dari nilai persentase setiap indikator yang disajikan pada Gambar 3.

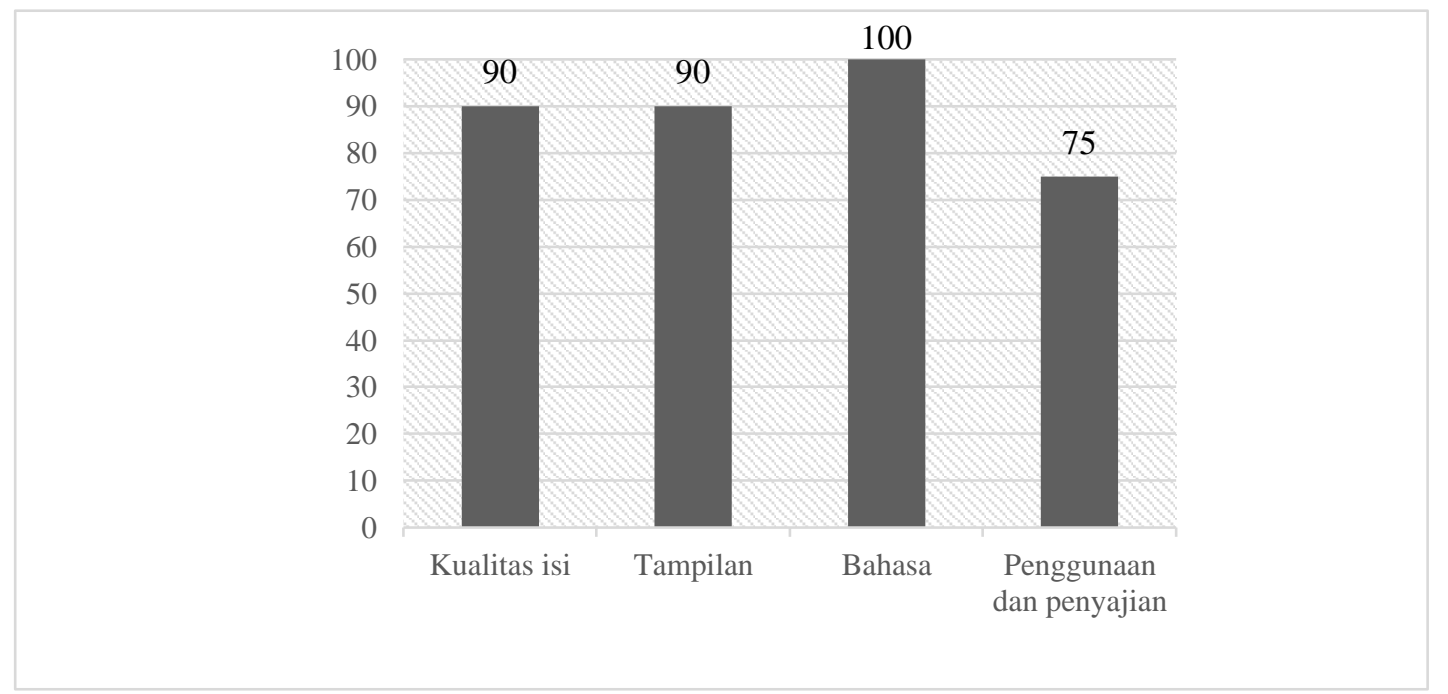

Gambar 3. Angket Respon Guru. 
Respon secara umum dapat diartikan sebagai hasil atau kesan yang diperoleh dalam suatu pengamatan. Peserta didik memberikan respon positif karena materi yang terdapat dalam handout IPA berbasis lingkungan alam sekitar dipadu peta konsep mudah dipahami sesuai dengan lingkungan alam sekitar peserta didik dan juga disampaikan dengan berbantuan peta konsep disetiap awal bab, agar peserta didik dapat mengetahui keterkaitan konsep materi satu dengan yang lainnya. Hal tersebut dapat ditunjukkan pada materi tekanan. Pada materi tekanan peserta didik dituntut untuk memahami tekanan hidrostatis, archimides, dan tekanan udara. Peserta didik dalam mempelajari materi tekanan disediakan peta konsep di awal bab agar peserta didik mengetahui keterkaitan konsep-konsep didalamnya, dan materi tekanan (hidrostatis, archimides, dan tekanan udara) disesuaikan dengan lingkungan alam sekitar peserta didik yaitu dengan cara melakukan percobaan sederhana untuk membuktikan penerapan konsep tekanan yang digunakan dilingkungannya. (Kusuma \& Aisyah, 2012) menyatakan bahwa tanggapan yang positif cenderung untuk menyenangi, menyukai, mendekati, dan mengharapkan sesuatu dari produk yang dikembangkan. Respon positif terhadap handout IPA berbasis lingkungan alam sekitar dipadu peta konsep juga dapat dilihat dari komentar peserta didik dan guru pada angket respon yang menyatakan bahwa produk yang dikembangkan menarik, baik, dan mudah dimengerti. Hasil nilai persentase setiap responden berbeda satu dengan yang lainnya. Perbedaan tersebut dikarenakan perbedaan latar belakang lingkungan peserta didik di SMPI Al-Aziz, sehingga skor yang diberikan pada indikator kesesuaian materi dan isi dengan lingkungan alam sekitarnya yaitu dengan kategori tidak baik. Hal tersebut menunjukkan perbedaan nilai persentase yang jauh dengan peserta didik yang memang lingkungannya sesuai dengan konten dan isi yang terdapat pada handout IPA berbasis lingkungan alam sekitar dipadu peta konsep.

Respon guru terhadap handout IPA yang berbasis lingkungan alam sekitar dipadu peta konsep dikembangkan juga dibutuhkan untuk menentukan kelayakan produk handout IPA berbasis lingkungan alam sekitar dipadu peta konsep yang dikembangkan. Respon yang diberikan juga dapat membantu peneliti untuk mengetahui kelebihan dan kekurangan produk. Respon guru terhadap handout IPA berbasis lingkungan alam sekitar dipadu peta konsep yang dikembangkan dilakukan pada guru IPA di SMPI Al-Aziz. (Kusuma \& Aisyah, 2012) menyatakan bahwa seseorang akan memberikan respon yang positif apabila bagi orang tersebut sesuatu itu menarik. Salah satu aspek yang menggambarkan respon yaitu ketertarikan terhadap sesuatu yang diberikan. Hal ini juga terlihat ketika peserta didik, guru pengajar IPA, dan kepala sekolah SMPI Al-Aziz tertarik terhadap produk yang dikembangkan untuk digunakan agar dapat membantu proses belajar mengajar untuk kelas VIII di tahun ajaran selanjutnya.

Respon positif yang diberikan oleh peserta didik dan guru terhadap handout IPA berbasis lingkungan alam sekitar dipadu peta konsep dikarenakan bagi peserta didik dan guru produk yang dikembangkan menarik, baik, dan mudah dimengerti. Hal ini sesuai dengan komentar dari guru di SMPI Al-Aziz yang menyatakan bahwa handout IPA berbasis lingkungan alam sekitar dipadu peta konsep sangat cocok untuk digunakan di SMPI Al-Aziz. Hasil penelitian (Nerita, 2016) juga menyatakan bahwa handout bergambar disertai peta konsep pada materi ekosistem sudah valid untuk siswa SMP/MTs kelas VII di sekolah MTs Negeri Talaok.

\section{KESIMPULAN}

Handout IPA berbasis lingkungan alam sekitar dipadu peta konsep dari hasil validasi kelayakan isi materi, lingkungan alam sekitar, peta konsep, dan yang meliputi tampilan, format, bahasa, penggunaan dan penyajian sangat layak untuk digunakan. (2) respon peserta didik kelas sebesar 82\% (kategori sangat baik tanpa revisi) dan respon guru sebesar $89 \%$ (kategori sangat baik tanpa revisi). 


\section{DAFTAR PUSTAKA}

Ali, A., \& Arif, W. P. (2019). Developing of guidance for laboratory practice of islamic science-integrated plant anatomy-physiology. Biosfer: Jurnal Pendidikan Biologi, 12(1), 70-82.

BNSP. Standar Isi Kurikulum 2006 (2006). Retrieved from http://bsnp-indonesia.org/

Fajarianingtyas, D. A., Akbar, N. A., \& Herowati, H. (2019). Developing students' worksheet based on scientific approach in cell as the system of life. Biosfer: Jurnal Pendidikan Biologi, 12(1), 109-121.

Kusuma, F. W., \& Aisyah, M. N. (2012). Implementasi Model Pembelajaran Kooperatif Tipe Think Pair Share Untuk Meningkatkan Aktivitas Belajar Akuntansi Siswa Kelas XI IPS 1 SMA Negeri 2 Wonosari Tahun Ajaran 2011/2012. Pendidikan Akuntansi Indonesia, X(2), 43-63. Retrieved from DOI: 10.21831/jpai.v10i2.912.

Lamasai, M., Mestawaty, \& Puadi, I. (2014). Pemanfaatan Lingkungan Alam Sekitar Sebagai Sumber Belajar Dalam Meningkatkan Hasil Belajar IPA Siswa Kelas III SDN 10 Gadung, 5(3), 132-144. Retrieved from https://media.neliti.com/media/publications/114993-ID.

Lestari, P., Ristanto, R. H., \& Miarsyah, M. (2019). Metacognitive and conceptual understanding of pteridophytes: Development and validity testing of an integrated assessment tool. Indonesian Journal of Biology Education, 2(1), 15-24.

Majid. (2011). Perencanaan Pembelajaran Mengembangkan Standar Kompetensi Guru. Bandung: PT Remaja Rosdakarya Offset.

Mariyana, \& Nugraha, R. (2013). Pengelolaan Lingkungan Belajar. Jakarta: Kencana.

Mukhyati, \& Siti S. (2015). Pengembangan Bahan Ajar Perubahan Lingkungan Berbasis Realitas Lokal dan Literasi Lingkungan. Jurnal Pendidikan Biologi, 12, 151-161. Retrieved from https://media.neliti.com/media/publications/175255-ID-none.pdf.

Prastowo, A. (2012). Panduan Kreatif Membuat Bahan Ajar Inovatif Menciptakan Metode Pembelajaran Yang Menarik Dan Menyenangkan. Yogyakarta: Diva Press.

Ratnasari, R. D., Priantari, I., \& Hapsari, A. I. (2017). Pengembangan Mature Sebagai Bahan Ajar the Development of Mature, Jurnal Biologi dan Pembelajran Biologi, 2, 54-63.

Ristanto, R. H. (2011). Pembelajaran biologi berbasis inkuiri terbimbing dengan multimedia dan lingkungan riil terhadap prestasi belajar. Educatio, 6(1), 53-68.

Sumarsih. (2009). Implementasi Teori Pembelajaran Konstruktivistik Dalam Pembelajaran Mata Kuliah Dasar-Dasar Bisnis, Jurnal Pendidikan Akuntansi Indonesia, VIII(1), 54-62. Retrieved from DOI: 10.21831/jpai.v8i1.945.

Thiagarajan, Semmel, D., \& Semmel, M. I. (1974). Instructional Development for Training Teachers of Exceptional Children: A Sourcebook. ERIC. Indiana: ERIC.

Trianto. (2010). Mendesain Model Pembelajaran Inovativ-Progresif (Ketiga). Jakarta: Kencana Prenada Media Group.

Yusnaeni, Y., Lika, A. G., \& Hiul, S. (2019). Human respiratory system: designing student worksheet based on inquiry to promote 21 st-century skills. Biosfer: Jurnal Pendidikan Biologi, 12(1), 34-44. 